\title{
Saving antibiotics from themselves
}

For how much longer will antibiotics remain at the disposal of physicians? This is the question that will be raised in the public mind by the gloomy statement put out earlier this month from Boston by a group of participants in the conference on the Molecular Biology, Pathogenicity and Ecology of Bacterial Plasmids held in Santo Domingo last January. The statement, in which Professor Stuart B. Levy of Tufts University has played a prominent part, points to the spread of resistance to antibiotics among bacteria in recent years, says that the "worldwide public health problem" is "due in large part to the indiscriminate use of antibiotics" and goes on to urge that "national and international committees" should be set up so as to issue "directives for prudent antibiotic use". Dr Levy's group is anxious that attention should widely be paid to its clarion call.

Nobody dissents. The problem of antibiotic resistance, although something of a surprise because thirty years ago nobody anticipated the versatility of bacterial plasmids, is, nevertheless, not new. Good sense argues in the same direction as Dr Levy's group: plainly everybody - not merely physicians but public health of ficials and farmers - should be more discriminating in the use which they make of a class of compounds, for the time being invaluable, whose value is being eroded as the years go by. Less vitally (in the human sense), the same process has been happening with insecticides, the other principal biochemical legacy of the 1940s. Organisms of all kinds, not only bacteria but insects as well, constantly surprise us by their biochemical versatility. (So, too, do higher organisms such as human beings, which have demonstrated a remarkable capacity for survival in circumstances in which self-adulteration with materials such as alcohol is common, although there is no reason to suppose that selection has played any significant part in this process.) How do we learn to live with such surprises?

The question is every bit as important as the statement earlier this month makes out. It is more than merely wasteful, but tragic as well, that the benefits of technological innovations (antibiotics, insecticides) should irreversibly be misused. Superficially, these sombre prospects are more galling than the waste of the potential benefits of mechanical technology - air transport (hamstrung by protective regulation), telecommunications (often hamstrung by protective legislation) and computer technology (hamstrung by collective inertia). For there, the argument goes, the promise remains, waiting merely on some kind of reform of people's resolve to make sensible use of the tools that science and technology have provided for them. But is it not also tragic that in present circumstances the productive wealth of the industrialized nations should be constrained, with all the human consequences that are entailed - and measured by the growing proportions of the unemployed - and that the gap between the prosperity of the rich and the poor should, through mutual impoverishment, be sharpened? Society, in other words, is as much at risk from the under-use as from the over-use of the technology at its disposal.

How, against this background, should enlightened policies on antibiotics be designed? Dr Stuart Levy's group, recognizing that policies of some kind need to be devised, has been plainly at a loss to know how these might come into being. Why else would it have suggested a hierarchy of national and international committees? This strategem, the most obvious, is well calculated to amplify its own eloquent statement of foreboding about the consequences of the misuse of antibiotics, but unlikely to make much headway with dealing with the causes of misuse. These, in turn, are deeply embedded in the ways of societies blessed with the chance of using antibiotics - the freedom of physicians to prescribe, the freedom of other professional people (farmers, for example) to use chemical products in ways that they think proper and profitable and the general restraint on democratic government from excessive interference with what people do (or do not do). Dr Levy's group, for all the best reasons, finds itself up against the kind of social ethos that made the discovery of antibiotics possible. That, it may be thought, is the irony of their (and our) dilemma. How is it to be resolved?

The dismal science would suggest a simple remedy, not entirely to be scorned. If some uses of a potential social benefit are judged democratically to be prejudicial for society at large, why not put a tax on them? The snag is that the demand for antibiotics is greatest in those societies in which the prices of supposedly lifesaving drugs have the least negative effect on the demand for them; elsewhere, where the "need" is perhaps greatest, the "demand" (muted by the capacity to pay or even by ignorance) is least. An alternative solution may be found in the common ethics of the medical profession, which increasingly requires that physicians should balance the benefit that a single patient will receive from a certain treatment against the more general benefit if the resource in question is dispensed in some other way - the allocation of a kidney machine to one person rather than another, for example. In the use of antibiotics, the counterpoise of individual benefit is, however, non-use for the greater good. Logically, the problem is the inverse of that in which physicians subject their patients to the small risk of damage from the use of a vaccine (coupled with the benefit of immunity against the corresponding infection) for the sake of the wider benefit. The trouble is that non-use is certain to be regarded, in democratic societies, as deliberate and thus reprehensible neglect. How, in the last resort - as it may be - does a physician explain that the administration of an antibiotic likely to be beneficial must be withheld for fear that resistance will be encouraged?

Physicians properly concerned about problems of antibiotic resistance must manage more adequately to come to terms with the societies in which they work. It would, of course, in many other fields than this, be splendidly simple if individuals would put their expectation of personal benefit second to the communal benefit, even in matters of life or death. In the short run, however, that is exceedingly unlikely. And there is no immediate prospect that there will quickly arise such a persuasive analyst of the machinery of society that some compromise will be found between the doctrines of the two greatest analysts so far - Adam Smith (who can be bowdlerized as holding that the communal good is the sum of individuals' estimates of their individual benefit) and Karl Marx (whose essential argument, grossly oversimplified, is that the greater good will benefit most but not all individuals). So what should physicians do about antibiotics? The hierarchy of committees now proposed, potentially useful, should be given positive rather than negative terms of reference. The objective should be somehow to suggest things to do rather than not to do - handlists for physicians to help them to make empirical decisions, programmes for the more effective control of infection in hospitals, plans for helping forward the development of new kinds of antibiotics (for research people are even more adaptable than bacteria) and, above all, studies of how a proper balance between use and non-use is to be struck in modern democratic society. Nobody will pretend that these tasks are simple. In the long run, however, nobody will listen seriously to Dr Levy's group unless it tackles these broader subjects. 